\title{
PENGEMBANGAN DESAIN MOTIF UKIR UNTUK AKTUALISASI IDENTITAS JEPARA SEBAGAI KOTA UKIR
}

\author{
Agus Setiawan $^{1}$, Annas Marzuki Sulaiman ${ }^{2}$ \\ ${ }^{1,2}$ Program Studi DesainKomunikasi Visual, Fakultas Ilmu Komputer, Universitas Dian Nuswantoro \\ agus.setiawan@dsn.dinus.ac.id ${ }^{1}$, annas.sulaiman@dsn.dinus.ac.id ${ }^{2}$
}

\begin{abstract}
Abstrak
Jepara memiliki potensi besar dibidang seni ukir. Potensi ini dapat dilihat dari masa Ratu Kalinyamat dan R.A. Kartini. Motif ukir Jepara dapat dilihat sebagai kontruksi sosial dalam hubungannya dengan identitas kultural dan tradisi. Motif ukir Jepara telah menjadi identitas kota melalui wujud kreasi-kreasi motif ukir dan ditempatkan di berbagai sudut kota. Tujuan penelitian ini adalah berupaya menguatkan identitas Jepara sebagai Kota Ukir melalui pengembangan desain motif ukir. Solusi yang diusulkan penulis adalah sebuah pendekatan historis dan estetik desain. Pendekatan ini dapat diimplementasikan untuk menjelaskan pengembangan desain motif ukir di Jepara dan aktualisasi identitas Jepara sebagai Kota Ukir. Data-data yang digunakan berasal dari narasumber, tindakan, arsip dan sumber tertulis. Berdasarkan data-data yang dihasilkan dalam penelitian ini, maka penulis menentukan analisis secara siklus guna menjelaskan pokok permasalahan yaitu pengembangan desain motif dan identitas Jepara sebagai Kota Ukir.
\end{abstract}

Kata Kunci: desain, identitas, Jepara, motif ukir.

\begin{abstract}
Jepara have the great potential in the fields of carving art. This potential can be seen from the time of Ratu Kalinyamat and R.A Kartini. Carving motif of Jepara can be seen as construction social in conjunction with cultural identity and tradition. Carving motif of Jepara has become identity cities through carving motif forms that placed in various city corner. The purpose of this research is trying to strengthen Jepara identity as a carving city through design development carving motif. The solution proposed writer is an approach to historical and aesthetic design. This approach be able to be implemented to explain design development carving motif in Jepara and actual Jepara identity as a carving city. The data used originates from speakers, the act of, archive and source of written. Based on the data, the writers determine analysis to explanation the main issues that is the development of motif design and Jepara identity as a carving city.
\end{abstract}

Keywords : design, identity, Jepara, carving motif. 


\section{PENDAHULUAN}

World Carving Centre adalah ungkapan yang paling tepat untuk Jepara. Jenis motif ukir yang terdapat di Jepara sangat banyak ragam bentuknya, sebagai hasil pengembangan dari bentuk-bentuk motif ukir sebelumnya. Namun ciri khas bentuk motif ukir Jepara pada motif-motif baru masih dapat dijumpai seperti unsur daun dan bentuk relungnya. Semuanya memperlihatkan warisan keterampilan dalam mengukir baik dalam bentuk kasar maupun halus. Keistimewaan dari motif ukir yang terdapat di Jepara menunjukkan suatu bukti bahwa keberadaannya merupakan peninggalan sejarah dari penguasa-penguasa pada masa tertentu. Gustami mengungkapkan bahwa keterlibatan para tokoh dan pemimpin wanita dalam proses pembentukkan seni kerajinan mebel ukir jepara merupakan bukti keterkaitan pemimpin bangsa sebagai inspirator, inovator, dan penggerak untuk memacu bangkitnya semangat para seniman dan perajin dalam berkreasi [1].

Sejak zaman Ratu Kalinyamat dan R.A. Kartini, Jepara memiliki potensi besar di bidang seni ukir. Desain motif ukir hingga saat ini selalu mengalami perubahan, yang jelas tidak bisa lepas dari peran masyarakatnya. Motif ukir yang selalu dikembangkan oleh masyarakat setempat yang sampai sekarang masih dapat dijumpai di berbagai bentuk mebel ukir. Tampaknya peranan motif ukir bagi masyarakat Jepara sangat memberikan kontribusi yang sangat berarti dibidang kerajinan sebagai karya seni yang mampu menopang kehidupan sehari-hari, usaha-usaha pelestarian atau pengembangan terus dilakukan.

Motif ukir sebagai satu dari sekian wujud budaya masyarakat Jepara, keberadaanya tidak bisa dipisahkan. Sosiohistoris menunjukkan realitas kultural, ekonomi, dan politik yang dibentuk oleh dimensi ruang dan waktu. Ruang dan waktu ini telah diisi oleh pengrajin untuk terus bertahan dalam proses berkarya. Kegiatan dibengkel mebel (brak) dan showroom di sepanjang jalan penuh mebel berukir yang membuat konsumen akan terkagum-kagum. Desain motif ukir yang diciptakan memiliki nilai estetis dan dari sisi penerapannya menampakkan garapan yang tepat dan berkualitas. Desain motif ukir dalam menghias mengisi ruang-ruang kosong juga diterapkan pada bangunan-bangunan seperti makam, masjid atau rumah-rumah

Motif ukir tersebut tidak hanya terdapat di mebel ukir, tetapi juga dapat dilihat pada bangunan seperti masjid dan pendapa Kabupaten Jepara dan di ruang publik seperti taman kota, tugu di perempatan dan pertigaan jalan dan kawasan kabupaten Jepara, bahkan juga pada hiasan lampu hias kota kehadirannya dapat dianggap untuk memperindah kota Jepara. Di sisi lain, motif ukir Jepara juga diterapkan pada pakaian dinas dan sekolah. Motif ukir ini tidak berdiri sendiri secara utuh, keberadaannya menempel pada berbagai karya seni. Secara tidak langsung menunjukkan motif ukir Jepara sangat berperan. Motif ukir yang dihasilkan oleh masyarakat Jepara mampu memberikan citra bagi wilayah Jepara hingga menjadi "idiom" kota Jepara.

Jepara sebagai kota ukir sudah menjadi idiom dan sering kita dengar bahkan sampai saat ini sudah mampu menembus pasar ekspor karena produk mebel ukirnya. Jepara 
yang tidak mungkin dipisahkan dari pengertian Jepara sebagai kota ukir. Sehingga perkataan ukiran Jepara seakan-akan sudah merupakan idiom. Aktivitas mengukir dalam keseharian masyarakat Jepara mampu bertahan mengikuti perubahan zaman. Tantangan dan perubahan itulah yang mampu memikat konsumen untuk datang dan berkunjung ke Jepara hanya mendapatkan gambaran langsung tentang kemampuan masyarakat Jepara dalam hal mengukir [2].

Hal yang menarik dari motif ukir Jepara di samping memiliki bentuk yang khas, ada indikasi perwujudan kekuatan pengembangan terhadap mewujudkan karya seni yang menjadi kebanggaan masyarakat Jepara. Tetapi dalam proses pengembangannya bisa dianggap bahwa masyarakat Jepara tidak tahu hasil-hasil kreatif dari para perajin ukir apakah bentuk yang dihasilkan termasuk ke dalam bentuk yang mencirikan bentuk dari motif ukir Jepara, itulah yang menarik kalau melihat dari sisi warisan dan perkembangan bentuk motif ukir.

Motif ukir terpengaruh dengan berbagai budaya. Jika melihat hasil-hasil kerja kreatifnya, bentuk yang dihasilkan tetap mencerminkan lokal. Yang dimaksud adalah masih tetap membentuk karakter yang mencirikan visual dari bentuk-bentuk sebelumnya berdasarkan pengalaman masyarakat pendukungnya [3]. Motif ukir Jepara pernah mengalami puncak kepopuleran, ketika motif ukir diterapkan pada produk mebel ukir yang dihasilkan oleh para pengrajin. Bahkan hampir semua produk mebel ukir yang dihasilkan dipenuhi dengan hiasan motif ukir. Ini merupakan sedikit peran motif ukir untuk memenuhi keinginan masyarakat guna menunjang keindahan rumah dengan segala produk mebel ukir.

Dapat digambarkan motif ukir Jepara berperan besar dalam memajukan kota Jepara dalam proses adaptasi terhadap perubahan zaman yang terus berkembang. Pengembangan motif ukir dalam mencapai puncak kepopulerannya juga mengingatkan akan peran pemerintah yang sering menyerukan keindahan motif ukir. Dalam hal ini pemerintah sudah mengupayakan untuk memperkuat identitas Jepara sebagai kota ukir. Upaya yang sudah dilakukan di antaranya melalui perancangan komunikasi visual berbentuk tiga dimensi dan dua dimensi. Perancangan komunikasi visual tiga dimensi di tempatkan di bangunan, monumen, tugu, gapura yang keberadaannya berada di seluruh wilayah kota Jepara. Adapun perancangan komunikasi visual dua dimensi diterapkan pada majalah, web, Spanduk, poster, baliho dan sebagainya.

Berangkat dari latar belakang di atas terdapat hal yang menarik di antaranya pengembangan desain motif ukir yang tetap bertahan hingga saat ini oleh para pengajin. Desain motif ukir Jepara dapat diamati sebagai cerminan kontruksi sosial dalam hubungannya dengan identitas kultural dan tradisi. Motif ukir dijadikan identitas kota melalui wujud kreasi-kreasi motif ukir dan ditempatkan di berbagai sudut kota. Menggarisbawahi hal-hal yang telah dipaparkan di atas, maka sangatlah signifikan untuk dilakukan kajian lebih mendalam dengan judul "Pengembangan Desain Motif Ukir Untuk Aktualisasi Identitas Jepara sebagai Kota Ukir". 


\section{TINJAUAN PUSTAKA}

\subsection{Desain}

istilah desain grafis merujuk kepada proses perencanaan, memproyeksikan, koordinasi, memilih, dan mengorganisir serangkaian elemen-elemen tekstual dan visual untuk menciptakan komunikasi visual. Istilah desain juga digunakan dalam kaitannya dengan benda-benda yang diciptakan oleh proses itu [4]. Desain grafis adalah seni visual kreatif yang mencakup banyak bidang ilmu diantaranya yaitu seni, tipografi, tata letak halaman (layout), teknologi informasi dan aspek kreatif lainnya. Banyaknya cakupan bidang ilmu tersebut mengakibatkan para desainer dapat mengkhususkan diri dan fokus pada sub bidang tertentu pada bidang ilmu desain grafis [5].

Istilah desain komunikasi visual merupakan pengembangan dari kata desain dengan menghubungkannya dengan suatu media yang bertujuan mengkomunikasikan pesan tertentu. Setiap bagian dari desain komunikasi visual muncul merupakan sarana komunikasi yang membawa pesan tertentu, dan untuk mendapatkan respon yang diinginkan. Inilah sebabnya mengapa salah satu tidak bias menilai kualitas desain hanya atas dasar tampilan visualnya. Aspek estetika yang mempengaruhi suatu karya desain tidak boleh mendistorsi tujuan utama desain komunikasi visual, yang berpusat pada menghasilkan respon tertentu dari masyarakat tertentu [4].

Dalam perancangan sebuah desain yang maksimal dan tercapai tujuan yang diinginkan, maka perlu diperhatikan penyusunan unsur desain dan penggunaan prinsip desain yang tepat. Unsur desain tertuju pada "apa" yang digunakan dan prinsip desain tertuju pada "bagaimana" unsur desain tersebut diterapkan. Unsur desain meliputi: Garis, bentuk, ruang negatif, volume, nilai, warna, dan tekstur. Adapun, prinsip desain mencakup: Keselarasan (Harmoni), Kesebandingan (Proporsi), Irama (Ritme), Keseimbangan (Balance), dan Penekanan (Emphasis). Penerapan masing-masing prinsip secara spesifik dapat dipecahkan. Setelah masalahnya adalah diteliti dan didefinisikan dengan baik, elemen dapat dipilih, dan prinsip dapat diterapkan [6].

\subsection{Desain sebagai Warisan Budaya}

Warisan budaya dimaknai sebagai karya, produk atau hasil budaya fisik dari tradisitradisi berbeda dan capaian tertinggi dalam spiritual yang berbentuk nilai dari masa lalu, kemudian menjadi unsur inti dalam jatidiri bangsa atau kelompok. Dari gagasan ini, warisan budaya yaitu hasil budaya fisik (tangible) dan nilai budaya (intangible) dari masa lalu. Warisan budaya fisik (tangible heritage) dapat diklasifikasikan menjadi warisan budaya tidak bergerak (immovable heritage) dan warisan budaya bergerak (movable heritage) [7]. Warisan budaya tidak bergerak umumnya terdapat di tempat terbuka dan terdiri dari atas: situs, tempat-tempat bersejarah, bentang alam darat maupun air, bangunan kuno dan/atau bersejarah, patung-patung pahlawan [8]. Warisan budaya bergerak umumnya berada di dalam ruangan di antaranya benda warisan budaya, karya seni, arsip, dokumen, foto, karya tulis cetak, audiovisual berupa kaset, video, dan film [8]. 
Warisan budaya tertulis dalam Pasal 1 dari The World Heritage Convention yang isinya memetakan warisan budaya fisik menjadi tiga, yaitu monumen, kelompok bangunan, dan situs. Adapun, warisan budaya yang bersifat kebendaan berupa Benda Cagar Budaya, Bangunan Cagar Budaya, Struktur Cagar Budaya, Situs Cagar Budaya, dan Kawasan Cagar Budaya di darat dan/atau di air yang perlu dilestarikan keberadaannya sebab memiliki nilai penting bagi sejarah, ilmu pengetahuan, pendidikan, agama, dan/atau kebudayaan melalui proses penetapan (Undang-Undang Nomor: 11 Tahun 2010) (10) (World Heritage Unit, 1995: 45). Upaya pewarisan budaya salah satunya dengan pelestarian. Pelestarian merupakan upaya pemaknaan baru, dan dalam masyarakat yang pluralistik pemberian makna itu dapat beragam, maka pelestarian warisan budaya harus dapat dibicarakan bersama, dinegosiasikan dan perlu disepakati bersama pula melalui suatu dialog yang terbuka dan seimbang [9].

Pewarisan budaya (transmission of culture) merupakan tindakan proses mewariskan budaya dari satu generasi ke generasi masyarakat berikutnya melalui proses pembudayaan. Sesuai dengan spirit dan budaya sebagai milik bersama masyarakat, maka unsur kebudayaan itu menyatu dalam individu masyarakat dengan jalan diwariskan atau dibudayakan melalui tindakan proses belajar budaya. Tindakan proses pewarisan budaya dilakukan melalui proses enkulturasi (pembudayaan) dan proses sosialisasi (belajar atau mempelajari budaya). Pewarisan budaya pada dasarnya dilaksanakan melalui empati lingkungan keluarga, masyarakat, sekolah, lembaga pemerintahan, perkumpulan, institusi resmi, dan media massa. Melalui tindakan proses pewarisan budaya maka terbentuk manusia yang memiliki kepribadian selaras dengan lingkungan alam, sosial dan budayanya disamping kepribadian yang tidak selaras (menyimpang) dengan lingkungan alam, sosial dan budayanya [10].

\subsection{Identitas Kota}

Kota merupakan artefak yang dihuni. Kota sebagai lingkungan buatan manusia yang memperlihatkan karya besar dan kompleks, terdiri dari kumpulan bangunan serta manusia dengan konfigurasi tertentu membentuk satu kesatuan ruang fisik (physicalspatial entity) [11].

Kota adalah tempat kumpulan bangunan dan manusia (cities are place made up of buildings and people) [12]. Kota adalah artikulasi ruang yang memberikan suatu pengalaman ruang tertentu kepada partisipator [13]. Oleh karena itu, lingkup perhatian perancang kota akan lebih lengkap jika meliputi bangunan, setting dan karakter kota. Berdasarkan pengertian di atas dapat dipahami bahwa setiap kota dalam rancangannya tidak dapat lepas dari upaya memahami karakter kota, sehingga apa yang dimaksud karakter adalah persoalan yang menyangkut identitas.

Secara epistimologi, kata identitas berasal dari kata identity, yang berarti (1) kondisi atau kenyataan tentang sesuatu yang sama, suatu keadaan yang mirip satu sama lain;

(2) kondisi atau fakta tentang sesuatu yang sama diantara dua orang atau dua benda;

(3) kondisi atau fakta yang menggambarkan sesuatu yang sama diantara dua orang (individualitas) atau dua kelompok atau benda; (4) Pada tataran teknis, pengertian 
epistimologi diatas hanya sekedar menunjukkan tentang suatu kebiasaan untuk memahami identitas dengan kata "identik", misalnya menyatakan bahwa "sesuatu" itu mirip satu dengan yang lain [13].

\section{METODE PENELITIAN}

Penelitian ini menggunakan pendekatan kualitatif yang menjelaskan permasalahan melalui pengambilan data dari Dinas Pariwisata dan Kebudayaan, Dinas Perdagangan, Museum Kartini, dan Humas Pemda Kabupaten Jepara. Pendekatan kualitatif adalah suatu proses penelitian dan pemahaman yang berdasarkan pada metodologi yang menyelidiki suatu fenomena sosial dan masalah manusia. Pendekatan menghasilkan suatu gambaran permasalahan dengan meneliti kata-kata, laporan terinci dari pandangan informan atau narasumber, dan melakukan studi pada situasi yang alami [14]. Penelitian ini mendeskripsikan sosiohistoris Jepara, keberadaan Motif Ukir Jepara. Sebagai identitas Kota Ukir.

\section{PEMBAHASAN}

\subsection{Sejarah dan Sosial Budaya Masyarakat Kabupaten Jepara}

1. Sejarah Kabupaten Jepara

Kabupaten Jepara adalah salah satu kabupaten di Provinsi Jawa Tengah yang berbatasan dengan Laut Jawa di barat dan utara, Kabupaten Pati dan Kabupaten Kudus di timur, serta Kabupaten Demak di selatan. Wilayah Kabupaten Jepara juga meliputi Kepulauan Karimunjawa, yang berada di Laut Jawa. Kabupaten Jepara terletak di pantura timur Jawa Tengah yang bagian barat dan utaranya dibatasi oleh laut. Bagian timur wilayah kabupaten ini merupakan daerah pegunungan. Wilayah Kabupaten Jepara juga meliputi Kepulauan Karimunjawa, yakni gugusan pulau-pulau di Laut Jawa.

Kabupaten Jepara memiliki perjalanan sejarah yang cukup panjang, secara factual terdapat dua faktor penting yang menjadikan Kabupaten Jepara sebagai salah satu di antara sederetan nama kota terkenal di Indonesia, yaitu Jepara sebagai Kota Ukir dan Jepara sebagai Kota Kartini. Di sisi lain, Kabupaten Jepara memiliki periodisasi yang cukup penting dalam sejarah yaitu periodisasi kerajaan zaman Hindu, Kabupaten Jepara merupakan pelabuhan pantai utara Jawa yang berfungsi sebagai pintu gerbang komunikasi antara kerajaan di Jawa dengan beberapa Negara tetangga (India dan Cina). Demikian pula, pada periodisasi Kerajaan Islam di Jawa yang berpusat di Demak, Kabupaten Jepara juga tetap bertahan sebagai pelabuhan utara. Bahkan, Jepara sebagai pelabuhan pusat perdagangan terbesar, juga sebagai pangkalan armada perang yang lebih lanjut terkenal dengan usaha penyerangan Pati Unus (Putra R. Patah) terhadap kekuasaan Portugis di Selat Malaka tahun 1513 $\mathrm{M}[2]$.

Informasi yang lain tentang Jepara juga tercatat oleh penulis Portugis bernama Tome Pires dalam bukunya "Suma Oriental". Informasi ini menjelaskan bahwa pada abad ke-XV (1470 M) Jepara dikenal sebagai bandar perdagangan yang kecil yang baru dihuni oleh 90-100 orang dan dipimpin oleh Aryo Timur yang berada dibawah 
kekuasaan pemerintahan Demak. Aryo Timur kemudian digantikan oleh putranya yang bernama Pati Unus (1507-1521). Pati Unus dikenal sangat gigih melawan penjajahan Portugis di Malaka yang sangat berperan sebagai mata rantai perdagangan nusantara. Pada masa kekuasaanya, Pati Unus mencoba untuk membangun Jepara menjadi kota niaga. Setelah Pati Unus wafat, kekuasaanya digantikan oleh saudara iparnya yaitu Faletehan /Fatahillah yang berkuasa (15211536). Kemudian pada tahun 1536 penguasa Demak bernama Sultan Trenggono, menyerahkan Jepara kepada anak dan menantunya yaitu Ratu Retno Kencono bersama suaminya Pangeran Hadirin. Namun pada tahun 1546 terjadi kerusuhan karena perebutan tahta kerajaan Demak yang berlangsung setelah tewasnya Sultan Trenggono dalam Ekspedisi Militer di Panarukan Jawa Timur. Kerusuhan tersebut mengakibatkan tewasnya Pangeran Hadiri yang dibunuh oleh Aryo Penangsang pada tahun 1549 .

Dua puluh empat tahun kemudian pada bulan Oktober 1574, Ratu Kalinyamat kembali mengirimkan armada militernya yang lebih besar di Malaka. Ekspedisi militer kedua ini melibatkan 300 buah kapal dimana 80 buah kapal diantaranya merupakan jung besar berawak 15.000 orang prajurit. Pengiriman armada militer kedua ini di pimpin oleh panglima terpenting dalam kerajaan yang disebut orang Portugis sebagai "Quilimo".

Walaupun perang kedua ini berlangsung berbulan-bulan akhirnya tentara Kalinyamat juga tidak berhasil mengusir Portugis dari Malaka, namun peperangan tersebut telah membuat Portugis ketakutan dan jera untuk menghadapi Raja Jepara ini, hal ini dibuktikan dengan bebasnya Pulau Jawa dari Penjajahan Portugis di abad 16. Peninggalan sejarah dari perang besar antara Jepara dan Portugis tersebut sampai sekarang masih terdapat di Malaka berupa komplek kuburan yang disebut sebagai Makam Tentara Jawa. Ratu Kalinyamat juga sangat berjasa dalam membudayakan dan menghidupkan Seni Ukir yang hingga saat ini menjadi andalan utama ekonomi Jepara. Seni ukir Jepara ini merupakan perpaduan seni ukir Majapahit dengan seni ukir Patih Badarduwung yang berasal dari Negeri Cina.Pada tahun 1579 Ratu Kalinyamat wafat dan dimakamkan di desa Mantingan Jepara, di sebelah makam suaminya Pangeran Hadiri.

2. Keadaan Budaya Masyarakat Jepara

Jepara sudah terkenal di Indonesia maupun di dunia sudah sejak zaman dulu. Reputasi kota Jepara telah menarik banyak kegiatan ekonomi yang berkaitan dengan produksi dan pengolahan mebel dari bahan kayu. Hingga saat ini, Jepara sudah menjadi salah satu sentra industri pada sektor pembuatan mebel kayu, sehingga keberadaan industri mebel Jepara mampu memberikan pengaruh positif bagi perkembangan industri di sektor lainnya. Keberadaan banyak ruang pamer mebel yang terdapat di Jepara merupakan suatu indikasi pertumbuhan keaneka ragaman pilihan bahan mebel dan desain, yang memerlukan ketrampilan tinggi. Tingginya kegiatan industri di Jepara ini telah memicu peningkatan perekonomian yang cukup pesat khususnya di Jepara dan wilayah sekitarnya sehingga menarik 
dukungan pemerintah setempat. Misalnya kebutuhan truk kontainer pengangkut mebel untuk ekspor mendorong pemerintah meningkatkan status beberapa jalan utama di kabupaten sebagai jalan provinsi. Hal ini berdapak positif, salah satunya adalah saat ini sebagian besar wilayah di kabupaten dapat dijangkau oleh truk kontainer sehingga terjadi peningkatan perekonomian yang ditandai dengan datangnya lebih banyak orang yang otomatis memajukan kegiatan perekonomian di Jepara. Selain itu upah minimum pekerja di Jepara disinyalir lebih tinggi dibandingkan dengan tempat lain di Provinsi Jawa Tengah.

Sektor industri mebel merupakan tiang penyangga utama perekonomian Kabupaten Jepara. Sektor industi ini dibedakan dalam empat kelompok yaitu industri besar, industri sedang, industri kecil dan kerajinan rumah tangga. Kategori Industri menurut Badan Pusat Statistik (BPS) tahun 2005, industri besar adalah perusahaan dengan jumlah karyawan atau tenaga kerja 100 orang ke atas. Industri sedang adalah perusahaan dengan jumlah tenaga kerja antara 20 - 99 orang. Industri kecil adalah perusahaan dengan jumlah tenaga kerja antara 5 - 19 orang dan industri rumah tangga mempunyai tenaga kerja kurang dari lima orang.

\subsection{Jepara Sebagai Kota Ukir}

1. Ukir Jepara dalam catatan legenda

a. Prabangkara sang ahli pahat

Dikisahkan seorang ahli gambit bernama Prabangkara yang hidup pada masa Brawijaya. Raja menyuruh Prabangkara untuk memnciptakan patung permaisuri Raja. Patung permaisuri yang tanpa busana itu dapat diselesaikan dengan sempurna. Hal ini mengakibatkan Raja Brawijaya menjadi curiga. Dengan suatu tipu muslihat Prabangkara dengan segala peralatannya dibuang dengan cara diikat pada sebuah layang-layang yang setelah sampai diangkasa diputus talinya. Dalam keadaan melayang-layang inilah pahat Parabangkara jatuh di suatu desa bernama Belakanggunung.

b. Sunging Badarduwung sang ahli ukir

Dikisahkan pada masa pemerintahan Ratu Kalinyamat, terdapat seorang Patih bernama Sungging Badarduwung. Patih Sungging Badarduwung yang berasal dari Campa (Kamboja) ternyata seorang ahli ukir. yang memiliki keterampilan mengukir yang baik [2]. Sungging Badarduwung adalah tokoh dibalik relief Masjid Mantingan yang merupakan bukti artefak peninggalan Ratu Kalinyamat. Karya relief Masjid Mantingan yang sampai saat ini dapat dilihat dan dinikmati sebanyak 114 relief pada batu putih. Sosok Sungging Badarduwung merupakan tokoh penting yang berperan terhadap pertimbangan konsep perancangan pembangunan dan penciptaan ornamen beserta pelaksanaan pembangunan masjid Mantingan [15].

\section{Perkembangan Industri Ukir Jepara}

Ukiran sudah menjadi kerajinan utama dari kota Jepara. Produksi ukiran dari kayu di Jepara berada pada tempat-tempat yang lekat dengan para ahli pahat ukir Jepara 
sebagai centre of production yaitu di Desa Mulyoharjo untuk pusat kerjinan ukir dan patung Jepara. Yang dimaksud disini adalah ukiran yang berasal dari kayu yang bisa berasal dari kayu jati, mahoni, sengon dan lain-lain. Di kota Jepara hampir di seluruh kecamatan mempunyai mebel dan ukir kayu sesuai dengan keahliannya sendirisendiri. Hasil dari kerajinan ukir Jepara bisa bermacam-macam bentuk mulai dari motif patung, motif daun, relief dan lain-lain. Menurut Rini Inharyani selaku kasi perdagangan dalam negeri Kab. Jepara bahwa untuk mendukung eksistensi seni ukir Jepara maka perlu promosi keluar negeri, seperti yang selama ini pemerintah lakukan. Tindakan promosi ini sebagai upaya meningkatkan nilai ekspor di sisi lain, tetap mengenalkan mebel ukir yang selama ini mengalami penurunan. Permintaan konsumen cenderung minimali stanpa adanya hiasan ornamen.

Gustami mengungkapkan bahwa, eksistensi seni ukir tidak lapas dari peran tokoh dalam perkembangan industri mebel Jepara dalam empat periode waktu, sebagai berikut:

a. Periode Ratu Shima Tokoh Wanita Pada Masa Hindu

Berupa peninggalan (artefak) yang ditemukan di daerah Keling yang diduga berasal dari zaman pemerintahan Ratu Shima, yang pada waktu itu memerintah dengan adil dan bijaksana. Kerajaan Ratu Shima dikelilingi oleh pagar dari bambu yang kuat.

b. Periode Ratu Kalinyamat Tokoh Wanita Pada Masa Islam

Sekitar sembilan abad kemudian, di Jepara lahir tokoh perempuan lain, yaitu Ratu Kalinyamat. Beliau adalah sosok seorang patriot, pemberani, ahli seni dan strategi perang. Ratu Kalinyamat memiliki perhatian yang besar pada bidang seni kerajinan dan pertukangan dimana pada masa itu berkembang suburyang membawa dampak pada hubungan international yang terjalin baik pula.

c. Periode Raden Ajeng Kartini Tokoh Wanita pada Masa Kolonial

Tiga abad sesudah surutnya pemerintahan Ratu Kalinyamat, lahirlah tokoh perempuan lain, yakni Raden Ajeng Kartini yang terkenal dengan masa emansipasi wanita, karena beliau menaruh perhatian besar pada bidang pendidikan, khususnya untuk kaum perempuan. Beliau melihat adanya ketidakadilan pada perempuan yang tidak boleh memperoleh pendidikan yang lebih baik dari seorang pria. Selain pada bidang pendidikan, beliau juga memberikan perhatian pada bidang seni kerajinan dan ukir serta pertukangan. R.A Kartini berhasil menciptakan seni ukir baru dan menyebarkanya ke berbagai daerah serta mempromosikan mebel ukir Jepara ke luar negeri.

d. Tien Soeharto Tokoh Wanita pada Masa Kemerdekaan dan Pembangunan

Tien Soeharto dikenal sangat perhatian dalam bidang seni dan budaya, beliau membangun pusat-pusat seni dan budaya diantaranya TMII. Karena kecintaannya pada dunia seni dan budaya, Tien Soeharto mempromosikan mebel ukir Jepara melalui penyediaan ruang Jepara di Istana Negara. Dalam masa itu, Jepara menjadi pusat industri mebel ukir di Jawa Tengah khususnya, dan di Indonesia pada umumnya [1]. 
Mebel Ukir Jepara mempunyai ciri khas yang kuat yaitu salah satu ciri khas yang terkandung didalamnya adalah bentuk corak dan motif. Untuk motif sendiri bisa kita lihat dari: Daun Trubusan terdiri dari dua macam yaitu keluar dari tangkai relung dan keluar dari cabang atau ruas.Ukiran Jepara terlihat dari motif Jumbai atau ujung relung yaitu daunnya mekar menyerupai kipas, sementara pada ujung daunnya meruncing. Terdapat beberapa buah yang secara umum terdiri dari tiga atau empat biji yang melekat pada pangkal daun. Di sisi lain, tangkai relung memutar, memanjang, dan menjalar membentuk relung-relung kecil yang mengisi ruang atau memperindah. [2]

Namun pelaku industi mebel dan kerajinan di Jepara dalam bebarapa tahun belakangan ini cukup resah dengan eksistensi usahanya karena pesaing dari negara lain yang semakin kuat, serta masuknya industri di sektor lain di Jepara. Sampai saat ini, banyak perusahaan mebel di Jepara yang sudah merumahkan karyawannya lantaran semakin berkurangnya pesanan dari buyer. Sehingga para pengrajin ukir Jepara berharap dukungan pemerintah untuk mengembangkan industri ini untuk bersamasama menjaga marwah Jepara sebagai kota ukir dan mebel, dengan memberikan fasilitasi kepada pelakau industri mebel Jepara dalam berbagai pameran skala internasional untuk mendongkrak pasar [16].

\subsection{Keberadaan Motif Ukir Jepara untuk Identitas}

Motif ukir yang menjadi andalan masyarakat Jepara telah menjadi kekuatan bagi perkembangan pemerintah sebagai ujung tombak perekonomian, sehingga timbul kekuatan untuk tetap melestarikan dan menguri-uri budaya seni ukir. Wawancara dengan lana Cholidah mengungkapkan bahwa untuk melihat seni ukir jepara dari sudut pariwisata maka kami dinas pariwisata tetap memunculkan motif ukir dalam logo pariwisata. Tindakan ini merupakan salah satu bentuk untuk menguatkan posisi Jepara yang memiliki sejarah dan budaya seni ukir yang cukup lama.

Keberadaan seni ukir sebagai ikon diaplikasikan ke dalam berbagai media sehingga mampu mewujudkan Jepara sebagai kota ukir. Lebih lanjut Cholidah mengukapkan terkait bentuk ukiran pada logo pariwisata adalah berupaya membranding sebagai kota ukir melalui kegiatan atau even pariwisata. Penguatan seni ukir ini tidak hanya pada mebel atau bangunan, namun mewujud dalam aksi tindakan wisata yang satu sama lain bersinergi misal wisata desa, penggarapan oleh-oleh khas baik dari produknya maupun kemasan harus mengandung unsure ikonik motif ukir Jepara. Keberadaan desain motif ukir dan pengaplikasiannya dapat dilihat dari beberapa desain dan media di antaranya logo Kab. Jepara, logo Pilbup KPU Jepara, logo pariwisata Kab. Jepara, media umbul-umbul, dan gapura dibeberapa instansi pemerintah. Berikut wujud desain motif dan media yang digunakan untuk mendukung identitas Jepara sebagai kota ukir. 
1. Motif ukir dalam logo pemerintahan Jepara

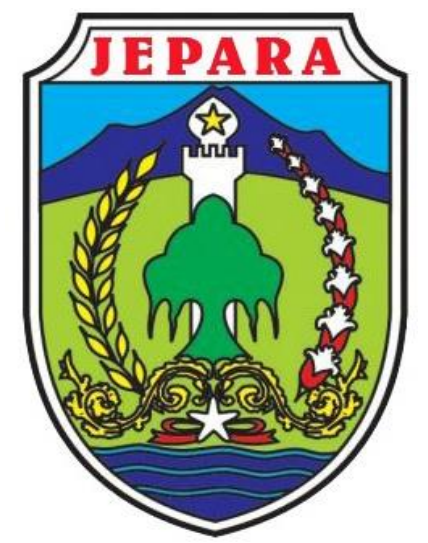

Gambar 3. Logo Kabupaten Jepara

[Sumber: upload.wikimedia.org, 2016] [17]

Makna bentuk dan motif-motif dalam lambang di antaranya perisai bersudut lima, bermakna perjuangan dan perlindungan. Gunung, bermakna kesentausaan serta ketenangan dan merupakan salah satu sumber kesuburan. Bintang bersudut lima, bermakna kepercayaan kepada Tuhan Yang Maha Esa. Menara, bermakna mayoritas penduduk kabupaten Jepara yang memeluk agama Islam. Pohon beringin, bermakna pengayoman dan persatuan adapun, sulur empat dan akar lima bermakna angka tahun 45. Ukir-ukiran relung motif Jepara, bermakna potensi unggulan, penuh kreasi dan terkenal sampai keluar negeri. Padi, bermakna kemakmuran dalam bidang pangan, berbiji 17 bermakna angka tanggal 17. Kapuk, bermakna produksi daerah yang terkenal tinggi kualitasnya dipasaran dunia, adapun, jumlah delapan buah angka bulan ke delapan. Perpaduan antara butir padi berbiji 17, kapok delapan buah dan sulur empat serta akar lima, merupakan rangkaian angka yang mewujudkan peristiwa bersejarah proklamasi kemerdekaan 17 Agustus 1945. Bunga melati, diikat dengan pita merah bermakna perjuangan dan kemajuan wanita serta menunjukkan tempat kelahiran pahlawan nasional RA Kartini. Tanah datar, bermakna kesuburan daerah, merupakan potensi pertanian dan perkebunan untuk kemakmuran. Laut, bermakna kebebasan, mengandung kekayaan alam yang melimpah ruah sebagai sumber mata pencaharian utama bagi para nelayan. Perpaduan antara langit, gunung, tanah dataran dan laut, menyiratkan kekayaan alam di daerah sebagai sumber kehidupan dan penghidupan rakyat. [18]

2. Motif ukir pada logo KPU Pemilukada Jepara

Sebagai bentuk kesadaran terhadap Jepara sebagai kota ukir, lembaga KPU turut andil dalam menyemarakkan pemilukada Pada tahun 2012 KPU telah mengadakan kompetisi tentang cipta desain logo KPU yang digunakan untuk Pilbup Jepara. Pesta demokrasi yang tidak lupa akan potensi daerah yang membanggakan bagi masyarakat Jepara. Kotak pemilu dipadukan dengan beberapa helai daun yang menggambarkan bentuk ukiran tampak tumbuh dari sudut kotak pemilu. Berikut 
desain logo KPU yang dipadukan dengan motif ukir yang mampu mendukung keberadaan Jepara sebagai Kota Ukir.

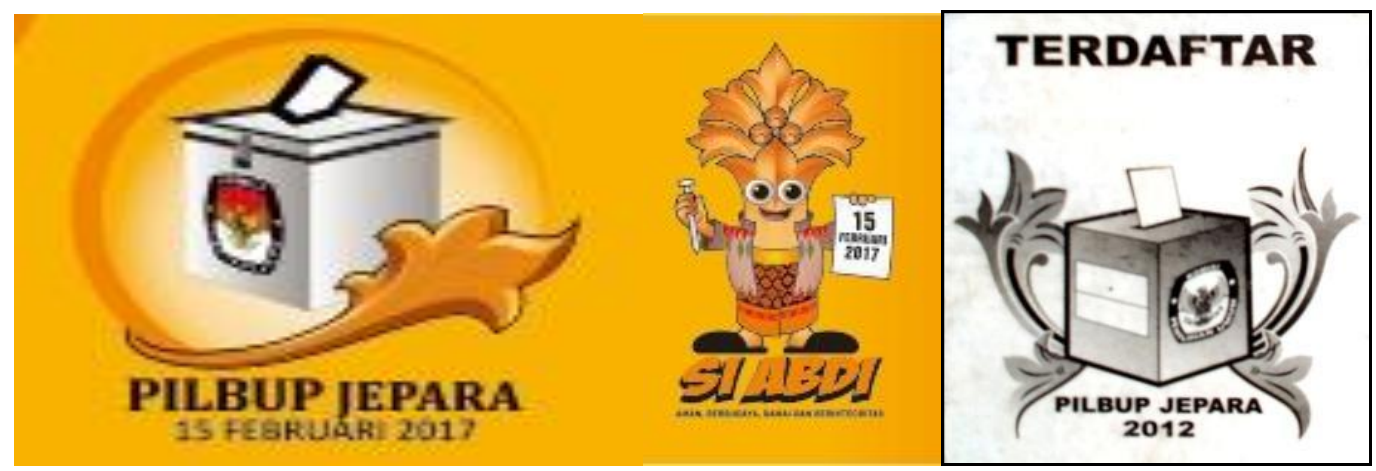

Gambar 4. Motif ukir pada logo KPU pemilukada Jepara tahun 2016 dan 2012

[Sumber: Agus \& Annas, 2016]

3. Motif ukir pada logo pariwisata Jepara

Logo pariwisata sudah mengalami beberapa perubahanya itu mengolah kata Jepara menjadi logotype. Logo pertama lebih menekankan pada huruf $\mathrm{P}$ sebagai center of interest yang sedikit dimodifikasi dan dibentuk dengan unsur ukiran berbentuk ukel. Adapun logo pariwisata yang baru lebih menekankan pada huruf J sebagai center of interest. Huruf J di dirancang seperti sulur-suluran motif ukir Jepara yang menjadi andalannya. Tampak tiga helai daun disusun seolah-olah tumbu dari tangkai. Logotype kedua dipadukan dengan unsur gelombang yang dianggap mencitrakan indahnya laut yang mempesona. Berikut logo pariwisata yang pernah diluncurkan untuk menguatkan image pariwisata yang tetap menunjukkan kekhasan Jepara sebagai Kota Ukir.
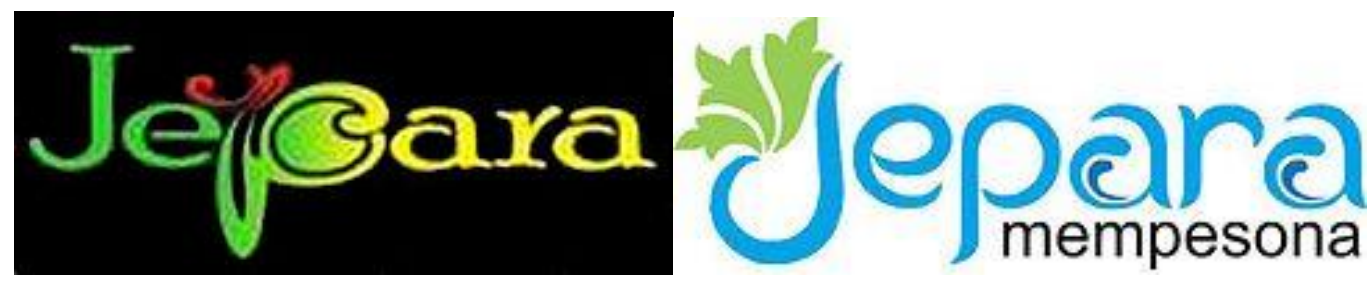

Gambar 5. Logo pariwisata Jepara, kiri lama kanan baru [Sumber: id.wikipedia.org, 2016] [19]

4. Motif ukir pada media promosi PemKab. Jepara

Aplikasi motif ukirpada media promosi menguatkan posisi Jepara sebagai Kota Ukir. Salah satu media adalah umbul-umbul yang didesain dengan motif ukir dan logo Kab. Jepara. Mendekati HUT RI, kehadiran umbul-umbul di sepanjang jalan utama kota Jepara banyak terpasang. Media ini digunakan untuk menguatkan citra Jepara sebagai Kota Ukir. Berdasarkan pengamatan terhadap media ini dimaksudkan bahwa gambar yang menunjukkan sebuah ukiran. Umbul-umbul yang terpasang menunjukkan desain motif percandian bukan relung yang selama ini dianggap sebagai ciri khas Jepara. 


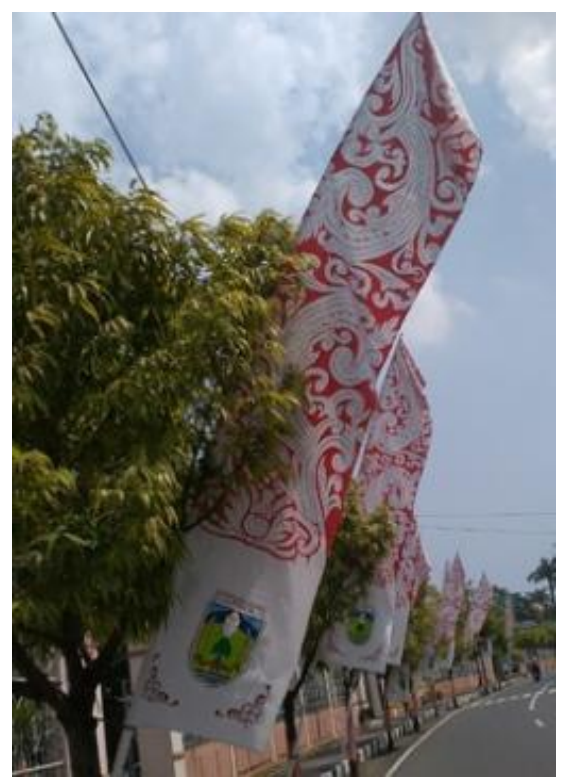

Gambar 6. Motif ukir pada media promosi PemKab. Jepara

[Sumber: Agus \& Annas, 2016]

5. Motif Ukir pada Seragam Batik Pemkab. Jepara

Tindakan dan kebijakan dari pemkab Jepara untuk mengukuhkan Jepara sebagai Kota Ukir salah satunya adalah motif ukir relung dalam pakaian kedinasan. Desain motif ukir yang biasanya hadir dalam ukir kayu kini diaplikasikan dalam batik. Bentuk relung disertai dengan beberapa daun yang mengembang menyerupai bentuk kipas.

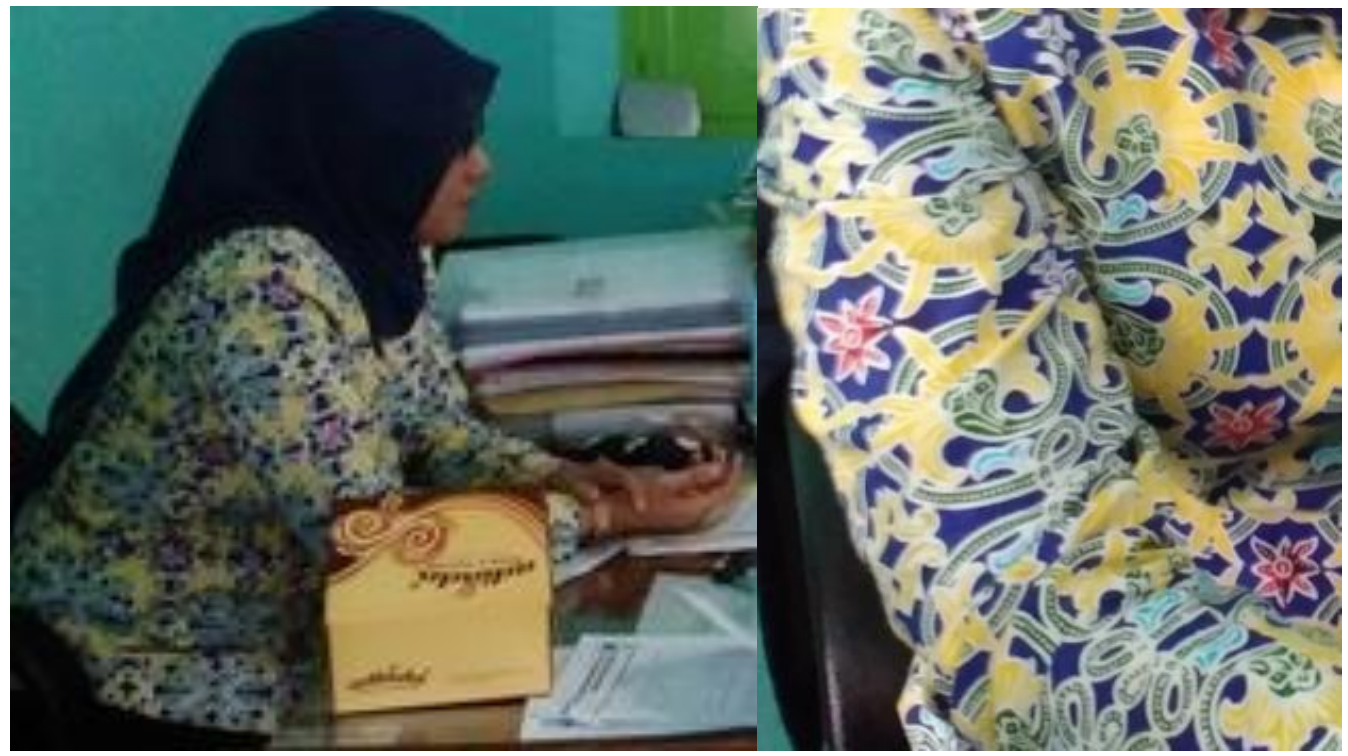

Gambar 7. Motif ukir pada pada seragam batik PemKab. Jepara [Sumber: Agus \& Annas, 2016] 
6. Motif Ukir pada pintu gerbang perkantoran PemKab. Jepara

Pintu gerbang atau gapura juga menjadi media komunikasi tentang keberadaan motif ukir. Gapura dengan ukiran relung teradapat dibeberapa instansi diantaranya dinas Pariwisata, Museum Kartini, SMPN 1 Welahan, Pendopo Kab. Jepara, dan Mesjid Agung Jepara. Berikut beberapa pintu gerbang dengan hiasan ukiran relung.

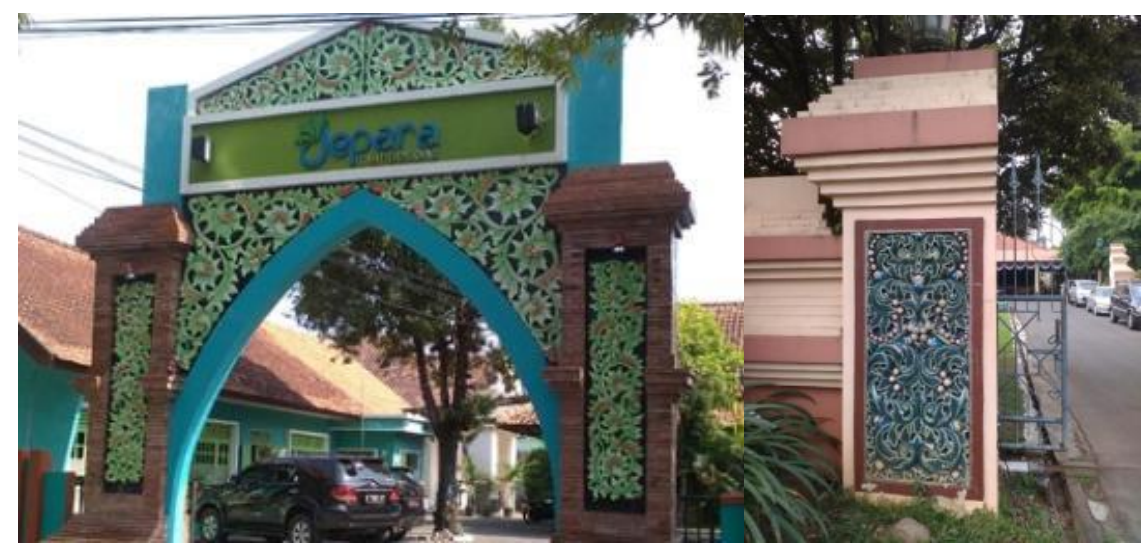

a

b

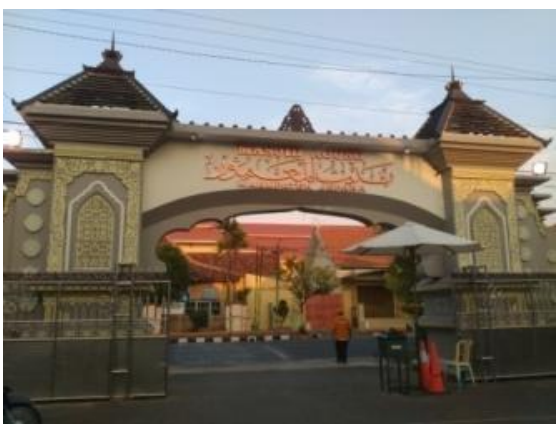

C

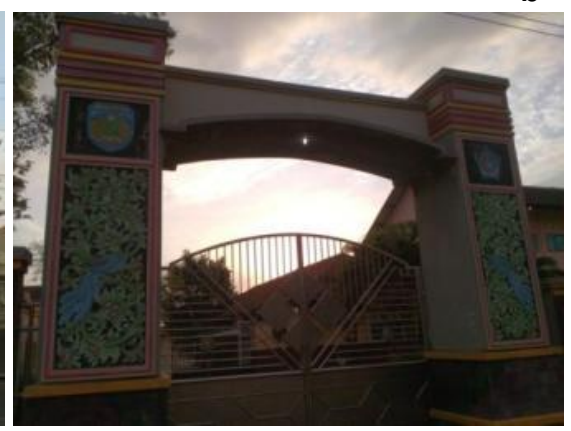

d

Gambar 8. (a) gapura dinas pariwisata, (b) gapura pendopo Kab. Jepara,

(c) gapura Mesjid Agung Jepara, (d) gapura SMPN 1 Welahan

[Sumber: Agus \& Annas, 2016]

\subsection{Pengembangan Desain Identitas Kota Jepara Berbasis Motif Relung}

Pengembangan desain motif ukir Jepara direncanakan akan memerlukan beberapa tahapan yang secara terjelaskan dalam bagan berikut ini:
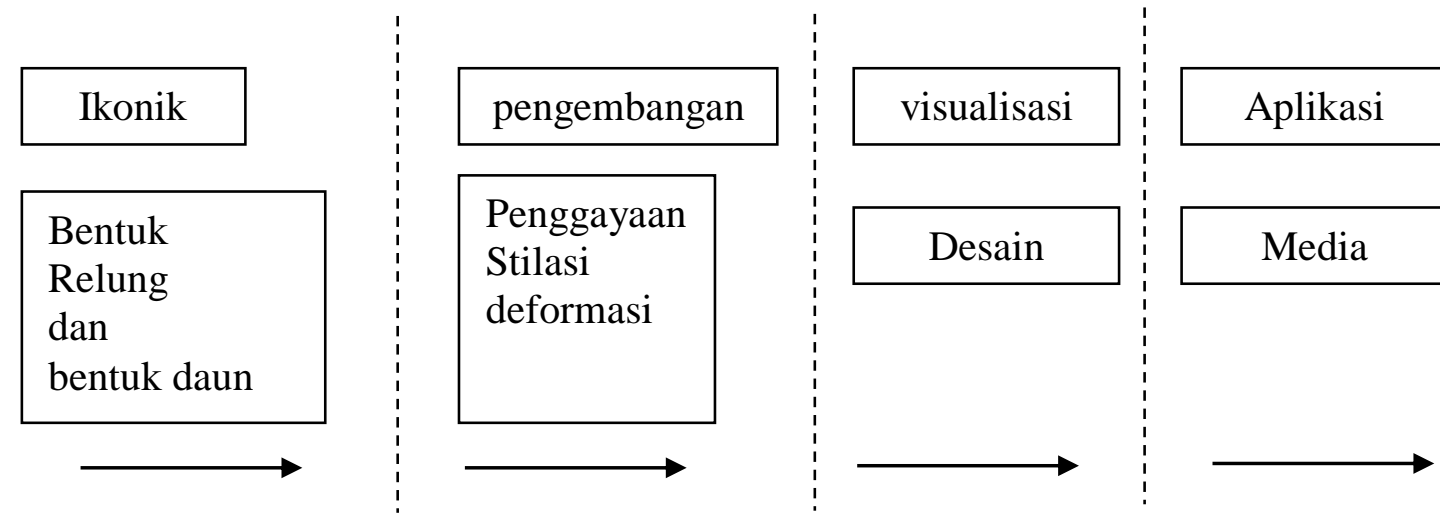

Gambar 9. Bagan pengembangan desain

[Sumber: Agus \& Annas, 2016] 
Langkah pertama, mengidentifikasi motif ukir sehingga menemukan secara ikonik dari bentuk motif ukir. Kedua mengembangkan ikonik motif ukir dengan cara melakukan penggayaan/stilasi/deformasi hingga dianggap cukup mantap untuk mencapai tahap ketiga yaitu visualisasi desain motif ukir Jepara. Berdasarkan hasil pengembangan maka di perlukan aplikasi media yang mampu menguatkan identitas Jepara sebagai Kota Ukir. Di sisi lain, pengembangan desain motif ukir dapat diterapkan sebagai brand promosi dalam kancah international. Brand promosi selalu hadir disetiap agenda/event, pameran yang dilaksakan di dalam dan luar negeri, sehingga kesan kuat dan citra positif dapat melekat pada masyarakat luas akan kualitas produk.
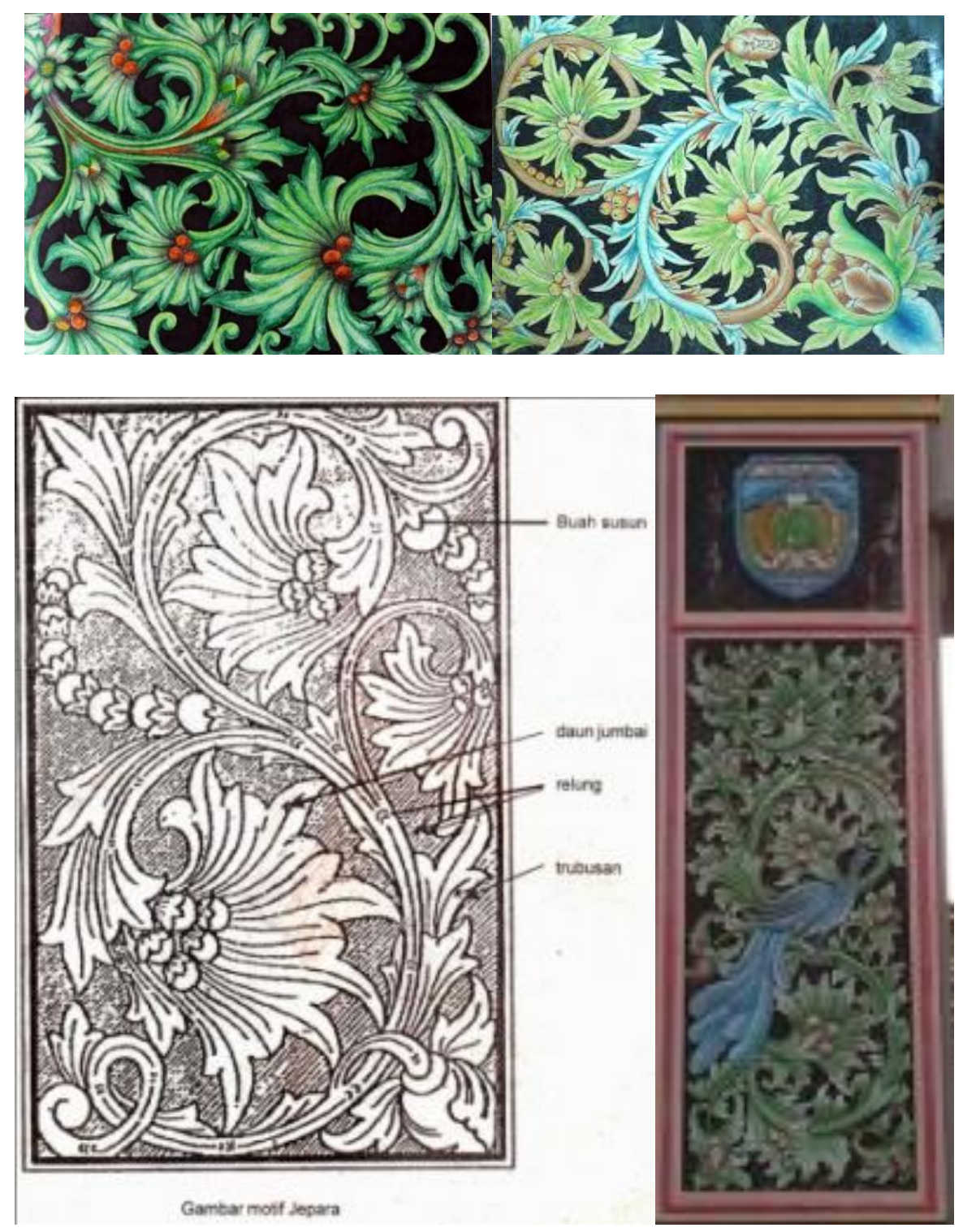

Gambar 10. Bentuk motif relung menjadi ikon motif ukir Jepara [Sumber: Agus \& Annas, 2016] 


\subsection{Pengembangan Digi-motif sebagai Penguat Identitas}

Bentuk desain motif ukir berbasis relung digunakan sebagai studi visual, sehingga pengembangan desain motif ukir untuk mengaktualisasikan Jepara sebagai kota ukir yang diharapkan mampu menciptakan brand promosi, city brand Jepara sebagai world carving center.

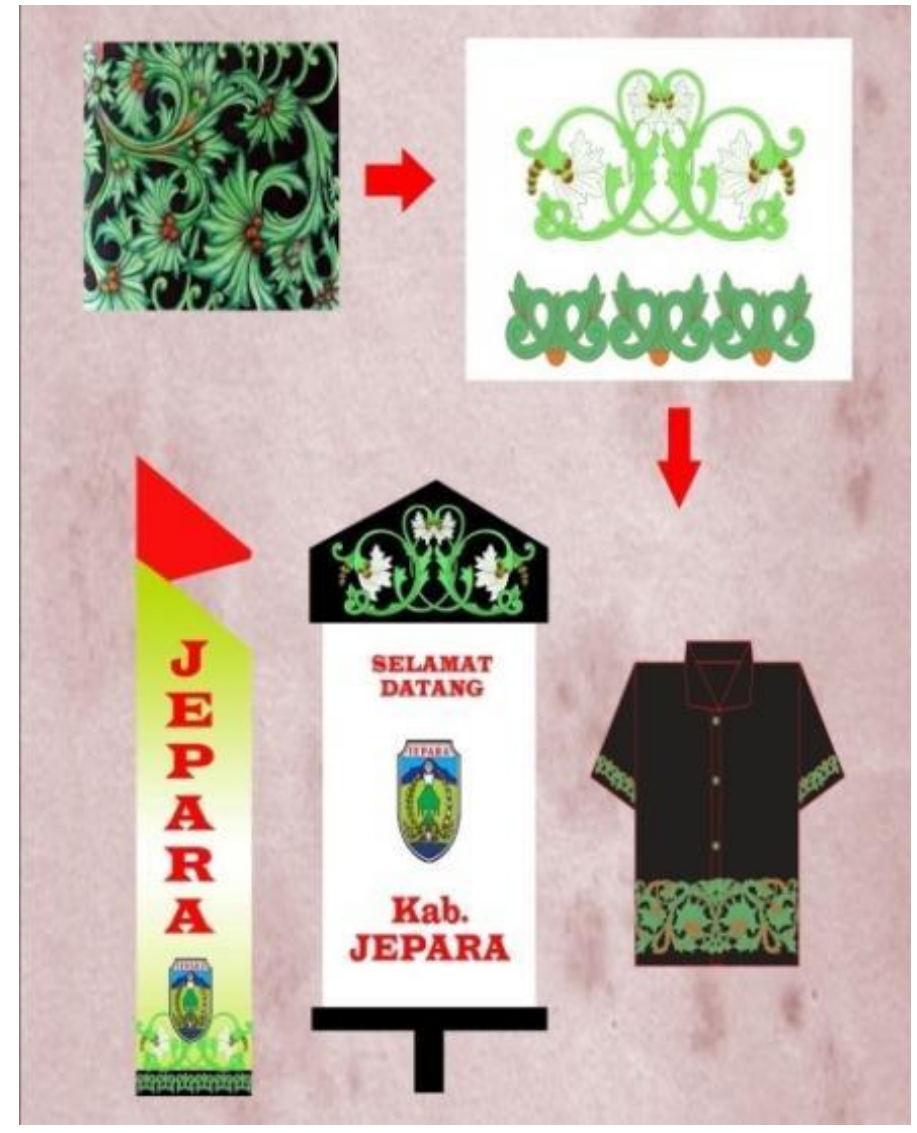

Gambar 11. Alternatif pengembangan Digi-motif dan rancangan aplikasi media [Sumber: Agus \& Annas, 2016]

\section{KESIMPULAN}

Jepara yang memiliki potensi besar dibidang seni ukir. Desain motif ukir hingga saat ini selalu mengalami perubahan, yang jelas tidak bisa lepas dari peran masyarakatnya. Keberadaan seni ukir sebagai ikon diaplikasikan ke dalam berbagai media sehingga mampu mewujudkan Jepara sebagai kota ukir. Penguatan seni ukir ini tidak hanya pada mebel atau bangunan, namun mewujud dalam aksi tindakan wisata yang satu sama lain bersinergi. Keberadaan desain motif ukir dan pengaplikasiannya dapat dilihat dari beberapa desain dan media di antaranya logo Kab. Jepara, logo Pilbup KPU Jepara, logo pariwisata Kab. Jepara, media umbul-umbul, dan gapura dibeberapa instansi pemerintah. Keseluruhan dianggap bagian dari upaya mewujudkan Jepara sebagai kota ukir. Desain motif ukir berbasis relung diharapkan mampu menciptakan tentang city brand Jepara sebagai world carving center. 


\section{DAFTAR PUSTAKA}

[1] Gustami. 2000. Seni Kerajinan Mebel Ukir Jepara. Yogyakarta: Kanisius.

[2] Kadir, Abdul. 1980. Risalah dan Kumpulan Data tentang Perkembangan Seni Ukir Jepara, Jepara: Pemerintah Kabupaten Daerah Tingkat II Jepara.

[3] Susanto, Mike. 2003. Membongkar Seni Rupa, Yogyakarta: Jendela,

[4] Frascara, Jorge. 2004. Communication design : principles, methods, and practice. New York: Allworth Press,

[5] Ambrose, Gavin, Paul Harris. 2009. The Fundamentals of Graphic Design, Singapore: AVA Publishing,

[6] Hashimoto, Alan, Mike Clayton. 2009. Visual Design Fundamentals: A Digital Approach, Boston: Cengage Learning,

[7] Davison, G. dan C Mc Conville. 1991. A Heritage Handbook. St. Leonard, NSW: Allen \& Unwin.

[8] Galla. 2001. A. Guidebook for the Participation of Young People in Heritage. Conservation. Brisbane: Hall and jones Advertising.

[9] Tanudirjo, D. A. 2003. Warisan Budaya untuk Semua: Arah Kebijakan Pengelola Warisan Budaya Indonesia di Masa Mendatang. Makalah disampaikan pada Kongres Kebudayaan V, Bukittinggi, 19-23.

[10] Arafah, Burhanuddin. 2003. "Warisan Budaya, Pelestarian Dan Pemanfaatannya". Artikel. Fakultas IImu Budaya. Universitas Hasanuddin (UNHAS).

[11] Siregar, A., Sandi, "Tata Bangunan dan Lingkungan di Kota Bandung" Artikel Seminar pekan kebudayaan Jerman Indonesia di Bandung berjudul "Prospek Bandung Menuju Kota Jasa di Era Globalisasi dilihat dari sudut pandang tata kota" 9 oktober 2003.

[12] Kostof, Spiro. 1991. The City Shaped, tanpa kota: tanpa penerbit.

[13] Bacon, Edmund. 1974.Design of Cities, New York: Penguin,

[13] Liliweri, Alo 2007. Makna Budaya Dalam Komunikasi Antar Budaya, Yogyakarta: PT LkiS Pelangi Angkasa,

[14] Creswell, J.W. 1998. Qualitatif Inquiry and Research Design, California: Sage Publications, Inc.,

[15] Setiawan, Agus. 2010. "Ornamen Mesjid Mantingan Jepara Jawa Tengah. Jurnal Dewa Ruci. Vol. 6 No. 02. Surakarta: ISI Surakarta

[16] "Industri Mebel Jepara" dalam .(http://amkri.org/amkri/2016/05/10/penguatanindustri-mebel-jepara-mendesak-dilakukan/?lang=id diakses tanggal 15 Mei 2016)

[17] "logo Kab. Jepara". (https://upload.wikimedia.org/wikipedia/i d/thumb/9/ 9f/Kabupaten_Jepara.png/150 px-Kabupaten_Jepara.png diakses tanggal 15 Mei 2016)

[18] "Lambang Kab. Jepara" dalam (http://www.kemendagri.go.id /pages/profildaerah/kabupaten/id/33/name/jawa-tengah/detail/3320/jepara di akses tanggal 15 Mei 2016) 
Andharupa, Vol.03 No.01 Tahun 2017

[19] "Logo Pariwisata". dalam (https://id.wikipedia.org/wiki/Kabupaten_Jepara diakses tanggal 15 Mei 2016) 